\title{
(16) 太平洋炭鉱の海外技術協力
}

\section{太平洋炭䃫怢釧路鉱業所 斎 藤 完 治}

1.はじめに

平成 4 年度から始まった新しい石炭政策は今年度で前 半の 5 年を終えようとしている。国内石炭産業の今後は 国民経済的役割と負担の均衡点までは国内炭生産の段階 的縮小を図ることが必要とうたわれている。

一方世界のエネルギー、特に石炭についてはアジア・ 太平洋地域における今後の急激な石炭需要の増加が見込 まれており、石炭の安定供給の面から産炭地域における 効率的な石炭生産の拡大と地球規模の環境保護の面から 環境に優しい石炭利用が求められている。このような状 況下にあって我が国のこれまで蓄積してきた優れた炭鉱 技術及び石炭利用技術を海外に於いて活用することは域 内の石炭安定生産・供給に貢献するだけでなく、エネル ギー源としての石炭の利用拡大にも繋がるものである。

国内石炭業界は存続のための自助努力を図ると共にこ のような使命を果たすため平成 2 年 10 月に石炭開発技 術協力セン夕（ J A T E C ）を設立し政策の下、国内炭 鉱技術の積極的活用による相手国石炭生産・利用に係わ る協力を実施しているところである。本文はこれまで太 平洋炭鉱釧路鉱業所で実施された海外石炭技術者の受入 れ研修、並びに当社技術者の海外派遣についての現状、 及び課題についてまとめたものである。

後述のように未だ改善を必要とする課題も多く皆様よ りの貴重な御助言を賜われば幸いである。

\section{受入れ研修者国別実績}

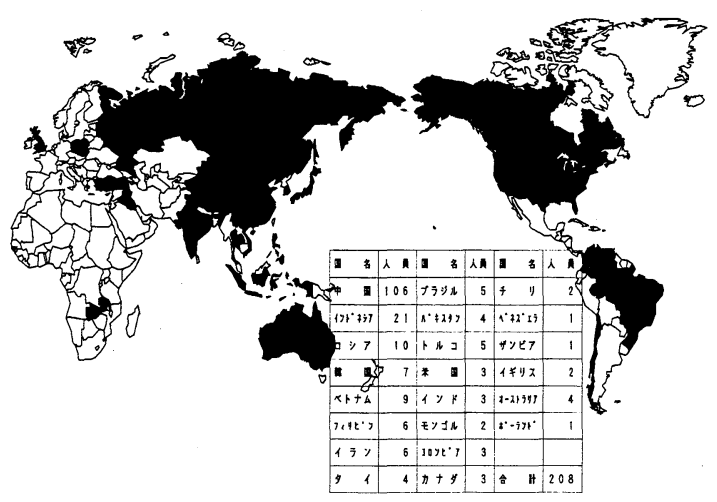

図 -1

\section{2. 受入れ研修}

平成 3 年度から始まった受入れ研修も年々 J A T E C の事業規模の拡大と共に対象国・人員が増加し、平成 7 年度末実績で 22 ケ国、208名に達している。

(仳 - 1)
（1）研修事業形態

研修事業は主にJ A T E C からの委託・請負によるも ので以下の事業から成っている。

J I C A 研修 :

国際協力事業団（ＪＩＣＡ） が実施する海外炭鉱技術 者研修の内一定期間を国内の炭鉱で実施する研修事業。

・採炭・選炭コース（アジア、南米他）

・鉱山保安コース（アジア、南米他）

・カウンターパート受入れ研修（韓国、トルコ）

AOTS 研修 :

海外技術者研修協会（AOT S ）の補助金を受けて J A T E C が開発途上国の炭鉱技術者を受入れて行う研修 事業。平成 7 年度迄毎年実施していたが、平成 8 年度は 予定なし。（中国、インドネシア）

M I T I 研修 :

資源エネルギー庁石炭部が「石炭鉱業構造調整円滑化 補助金事業」により「国内炭鉱技術活用可能性調查」の 一環として J A T E C に委託する受入れ研修事業。

(インドネシア、中国、ロシア、ベトナム)

NEDO研修 :

新エネルギー産業技術総合開発機構（NEＤＯ）が海 外炭の安定供給確保のために実施する「技術者交流事業」 のうち探査、生産、保安技術を対象として J A T E C に 委託する受入れ研修事業。(中国) その他 :

J A T E C 自主事業、及び石炭技術研究所（技研）が 実施する海外との保安技術共同研究の受入れ研修事業他。 （中国）（表－1）

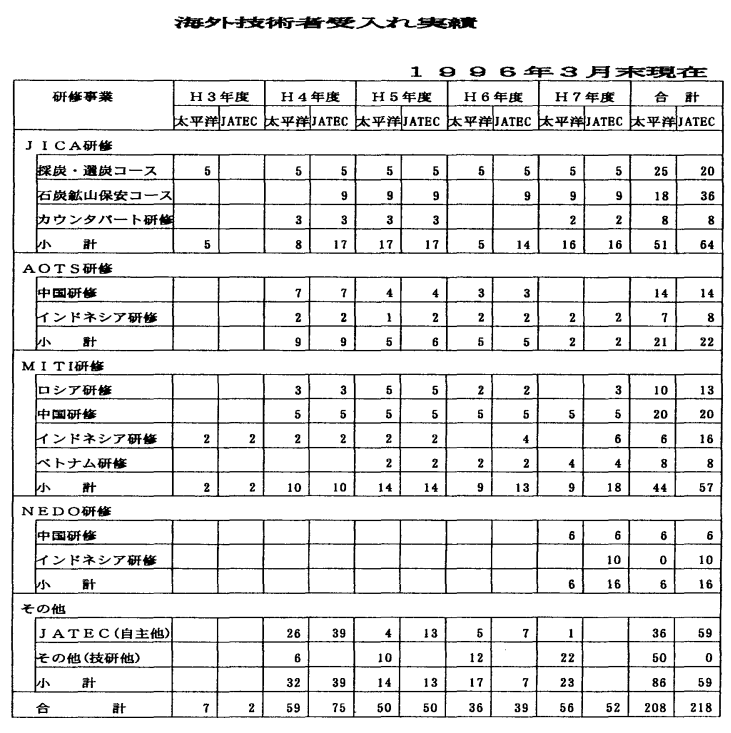
表 -1 
（2）研修組織・体制

従来の受入れは鉱業所研修センターのスタッフが受け 入れ業務を兼務し各専門スタッフが講師となり行われて いたが、受入れ・派遣事業の拡大に伴い平成 7 年 10 月 に専門部署として「国際技術交流室」を、さらに翌 4 月 に交流室の下に技術開発課と国際交流課を新設した。受 入れ業務は国際交流課が担当し、室長 1 名、課長 1 名、 係長 2 名、事務員 1 名の 5 名体制で受入れ業務全て、研 修プログラムの作成、資料作成、宿泊・食事・車の手配、 社内調整等を処理している。研修は交流室室長・課長及 び各課担当者（課長クラス）が講師となり行われている。 (図-2)

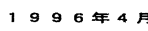

太平洋庭（株）釧路鉱菜所の技術者受入体制

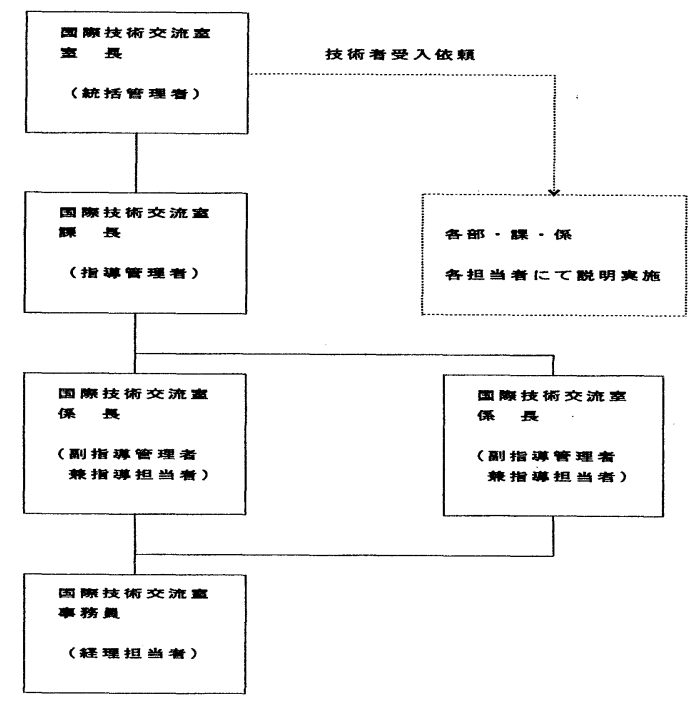

図-2

（3）研修施設と宿泊施設

主に研修センターで行われていたが、鉱業所内に新設 の研修施設に機能移転をおこなった。20 人用の講義室、 研修控室、外部講師控室、更衣室、シャワー室（6 室）、 トイレを備えている。

一方宿泊施設については当初社員独身寮を改造使用し ていたが平成 5 年度に炭鉱子会社のホテルにシングル 8 部屋、会議室、洗濯室を増築し生活環境を整えている。 (4) 研修内容

研修プログラムは研修期間、研修事業別に組み立てら れる。当初は生産・保安技術と運営内容が研修対象であ つたが、NEDOの技術者交流事業が始まって以降「経 営管理技術」が追加された。

生産・保安技術については稼働切羽、施設見学後各研 修項目共通で組織、運営法を紹介、その後項目別の技術 紹介及び質疑応答を実施している。

管理技術については 9 項目を用意し、実例を交えなが らの座学と問題解決手法による実技教育を実施している。
研修項目によってはビデオを利用している。ビデオは ばらつきはあるものの日本語、英語、中国語、インドネ シア語、スペイン語バージョンが用意されている。

研修資料は英語版、一部中国語版、ベトナム語版があ る。
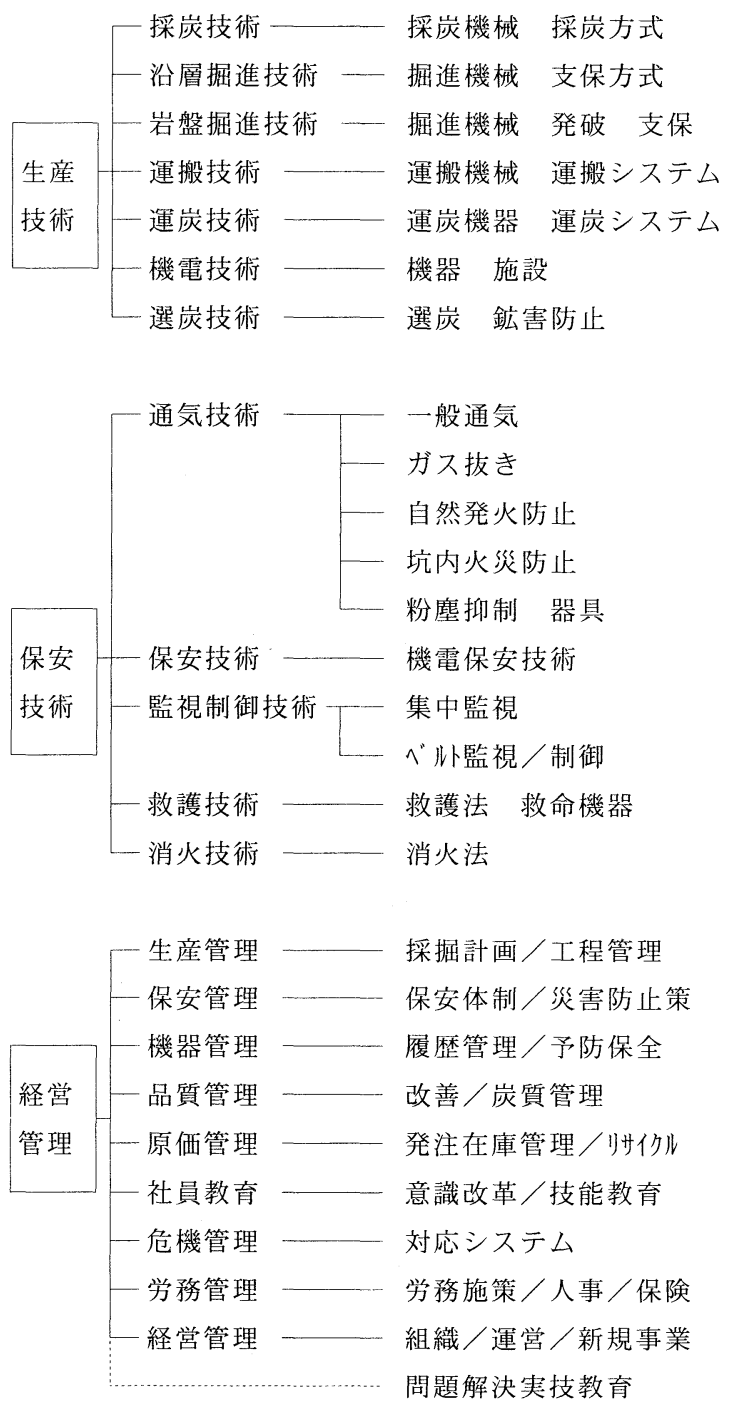

3. 海外派遣

海外技術者の受入れと並行して、当鉱技術者の海外派 遣を実施している。その形態は海外現地に於ける講習会、 技術支援、調査、技術協力、研修、及び当社自主事業か ら成り、当社事業を除き依頼元は主に J A T E C である。

当鉱技術者の海外技術協力に係わる海外派遣実績を 表一 2 に示す。派遣形態は以下の通り。

(1) 講習会

(1)海外研修会

A O T S の補助を受け、J A T E C が実施する研修事 業。坑内石炭採掘に於ける保安並びに生産の管理・改善 を通じ、安定出炭・供給に寄与することを目的とする。 
平成 4 年度より始まり中国で 1 回、インドネシアで 4 回 実施されており、当社より計 5 名の技術者が参加。各分 野のエキスパートにより炭釷開発・経営、探査、生産、 通気、選炭、救急法等についての紹介、その後現地参加 者との意見交換を行っている。平成 8 年度は予定なし。 (2)フォーラム

M I T I 「石炭鉱業構造調整円滑化補助金事業」によ る「国内炭鉱技術活用可能性調查」の一環として J A T E C が委託を受け実施。国内炭鉱技術の紹介と情報交換 を通じて、国内炭鉱技術の国際交流への可能性について 調査研究を目的とする。これまで 3 回中国で開催、生産、 通気、集中監視、選炭に係わる技術紹介がなされた。当 社からは計 3 名が参加した。

(3)ワークショップ

フォーラム同様、M I T I 事業による「国内炭鉱技術 活用可能性調査」の一環として J A T E C が委託を受け 実施。生産・保安に係わる国内炭鉱技術を紹介し、国際 交流の可能性調查を目的とする。過去 2 回開催されてい るが当社からは不参加。

(2) 技術支援

M I T I 「石炭鉱業構造調整円滑化補助金事業」によ る「国内炭鉱技術活用可能性調査」の一環として J A T E C が委託を受け実施する派遣事業。保安・生産に係わ る国内炭鉱技術の有効活用を図ると共に活用可能性の調 査を目的とする。現地での事前打ち合わせにより項目を 絞り込み、必要な人員と機材を現地炭鉱に持ち込み現場 実態に適応した技術支援を実施。。派遣者は各炭鉱会社 の各々専門技術者から構成。これまで計 5 回、当社から は計 10 名が参加。インドネシアの炭鉱にて実施。レッ グハンマーによる岩盤掘進技術、探査、採掘計画、採鉱、 及び機電に関する技術支援等がある。

他の形態としては技研が実施する海外保安共同研究へ の参加がある。中国へガス抜き技術支援で 1 名派遣して いる。

\section{(3) 調查}

主にM I T I の「構造調整円滑化補助金事業」及び 「鉱山保安技術調查委託事業」による調査事業、及び技 研の海外技術調查事業がある。前者事業は J A T E Cが 委託を受け実施している。派遣の中で最も人員の多い形 態で当初は途上国の石炭事情、特に中国、インドネシア、 ベトナム、ロシアの炭鉱調查が主であったが、その内容 が明らかになるに伴い他の国へシフトしてきている。

また最近は環境保護及びエネルギー多様化の観点から 品質管理、石炭利用、及び C M G に関する調查も始まっ ている。さらに J I C A スキーム（プロジェクト型技術 協力）を前提としたより具体的、実効の高い技術移転を 図るための事前調査が増えてきている。

石炭先進国への生産・保安技術調査も行われている。
年々拡大の傾向にあるが、これは海外の優れた技術・機 器を積極的に活用し、国内炭鉱技術のレベル向上と共に 国内炭鉱の技術がより一層海外の石炭開発に貢献出来る ことを目的としている。

(4) 技術協力

トルコにおける 5 年間を期限とする J I C A のプロ技 協が平成 7 年度から始まった。協力案件は保安機器、通 気管理技術等である。また平成 8 年度にも中国での石炭 環境保護保安センター構想に向け事前調查、専門家派遣 が始まる予定になっている。トルコへの協力事業には当 社関係者 2 名が参加している。

\section{(5) 研修}

N E D O による「技術者交流事業」の一環として炭鉱 技術、探查技術分野研修が平成 7 年度から中国、インド ネシアで始まっている。石炭の開発、生産性の向上を目 的とした研修事業で平成 8 年度は品質管理技術を追加す ると共に、炭鉱技術分野をインドネシアでも実施する予 定である。当社は昨年 5 名の技術者を中国山東省充州に 6 週間派遣している。今年も昨年同様 5 名を 8 月に派遣 予定。

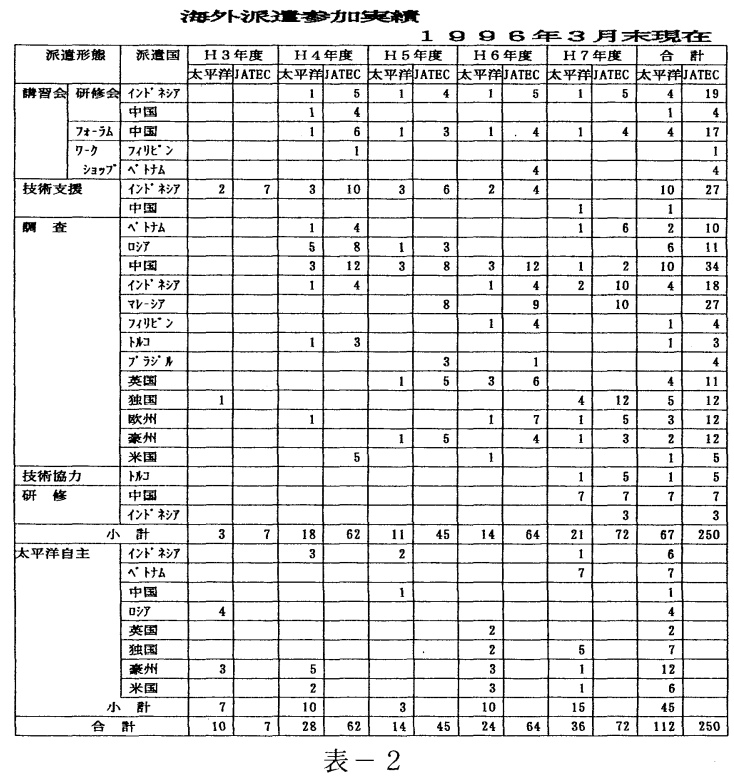

4. 人材養成

受入れ研修、海外派遣に伴って当社の若手石炭技術者 を盖成する必要から下記各種研修に積極的に参加させ人 材ポテンシャル向上に努めている。平成 7 年度末実績で 23 名。

(1) N E D O 炭鉱技術者養成研修

(2) J I C A 専門家盖成研修

(3) O V T A 海外派遣者養成訓練

(4) A O T S トレーナーズ、トレーニングコース 


\section{5. 今後の課題について}

J A T E C 事業は今年で 6 年目を迎え、その規模が拡 大すると共に内容が明確になってきた。これまでの経験 と今後のニーズを踏まえてより実効のある受入れ・派遣 を行う必要がある。

技術者の受入れ・派遣は国内炭鉱技術の海外における 技術協力・移転を目的としており、単に国内炭鉱技術の 紹介では不十分で、もっと相手国・炭鉱の実状に沿った 内容にする必要がある。その意味からすれば受入れ・派 遣とも一部プロジェクト事業があるものの総花的であり、 成果を評価する段階には至っていない。

技術協力・移転の最終目的はその対象技術が相手先に 有用であり、浸透・定着することである。炭鉱で言えば 坑内・現場条件に適し、生産性向上が図られ、保安の確 保に寄与できる、または環境問題に処する技術が導入さ れ、改良を加えながらも自分たちの技術として定着する ことであろう。その意味からすればこれまでの受入れ・ 派遣は緒についたレベルでありこれからが本番である。

今後の技術協力・移転を政策レベルで推進していくた めのポイントは以下の 4 項目に絞られるのではないかと 思う。

(1) 既存技術活用の評価

既存の炭鉱技術はその炭鉱の様々な条件（例えば自然 条件）の下に開発・改良されてきたのであるから、相手 先の炭鉱条件が正確に把握され、それを踏まえた適用評 価、つまり炭鉱技術と言つても広くざの技術が移転可能 で、実効が高いかを明確に判断することがポイントとな る。

(2) 技術者育成

対象案件が絞り込まれても日本から機材だけ持ち込め ばそれで足りるという場合はまず無いといってよい。現 地の条件に対応した改良も必要であろうし、相手技術者 への教育も含めた円滑なコミュニケーションが求められ る。食事、生活環境も違う状況で結果が出るまでの期間 活き々と仕事をこなせる技術者を育成する必要がある。

(3) 海外拠点

相手技術者への研修を効率よく行える、また研修後の フォローが行える研修・研究施設を持ち、双方の技術者 が交流できる拠点が必要である。この拠点を介し情報の 収集、人的交流を広げ円滑な技術協力・移転を進めると 共に相手国内への浸透・拡大化が可能となる。

また国内拠点との最新情報のやりとり、受入れ・派遣 の調整も的確に行なえる。

(4) 国内拠点

海外現地移転対象の技術がうまく定着、実効をあげて いる場、または技術開発の場としての国内拠点が必要で ある。相手技術者に実際に自分たちの目でその技術を確 認してもらうことは非常に重要であり彼らの自信につな
がる。また国内技術者との検討は技術移転に弾みをつけ るものである。この国内拠点と海外の拠点を技術交流の ゲートウェイとし機材供与・人的交流を図るべきである。 技術開発は現地で直接行うのがベストであろうが、資材 ・機器の調達、人材の規模、コミュニケーション等の問 題からプロットタイプは国内で製作し、実証後現地導入 ・改良を行うほうが時間的にも完成度合いにしても優れ ていると思われる。

上記 4 項目が整えられた上で技術協力・移転事業が立 ち上がったならば、技術者受入れ、派遣の目的が明確で あるからその効果は高いものになる。機材供与と技術者 派遣が一体となった協力形態でフォロー体制がとれ、さ らには相手国内での技術拡大が図れることが理想である。 適用技術及び派遣技術者の選択を誤らなければ、そして カウンターパートを始め相手先が前向きであれば結果は 自ずとついてくると考える。

\section{6.おわりに}

国際貢献とエネルギー供給の安定化のため我が国は炭 鉱技術の活用を積極的に推進していかなければならない。 国内石炭企業は新しい石炭政策のもと、非常に厳しい状 況に直面しているが、自主・自立経営を基本に存続を図 りつつ、上記目的のため受入れ体制、派遣技術者の盖成、 そして生産性・保安に優れた技術開発も併せて推進する 必要がある。そのためには官学産の一体となった協力体 制が必要であり、J A T E C （新団体）がその中心的役 割を担ってゆくと思われる。これまで培ってきた技術ノ ウハウを上記目的のために、有効利用できるならば、我 々は積極的に寄与してゆく所存である。

最後に、J A T E C をはじめ海外石炭技術者研修受入 れ、国内石炭技術者派遣事業に係わる各団体・組織の各 位に対し深く感謝する次第である。 